\title{
Impacts of Local Government Land Leasing Revenue on House Price - Based on National and Regional Panel Data Analysis
}

\author{
Jie DING ${ }^{1}$, Jian-Qiang LI $^{1} \&$ Qing KANG ${ }^{1}$ \\ ${ }^{1}$ College of Economics and Management, Sichuan Agricultural University, Chengdu 611130, China \\ Correspondence: Jie DING, Room 418, Unit 2, Building 6, School of Economics and Management, Sichuan \\ Agricultural University, 211Gongpinghuimin St, Wenjiang District, Chengdu 611130, China. Tel: 86-139-8171-5482. \\ E-mail: icelovejie@163.com
}

\author{
Received: April 16, 2012 \\ Accepted: May 7, $2012 \quad$ Published: July 1, 2012 \\ doi:10.5539/ijef.v4n7p88 \\ URL: http://dx.doi.org/10.5539/ijef.v4n7p88
}

\begin{abstract}
The purpose of this paper is to analyze the impacts of local government land leasing revenue on house price. Econometric analysis was employed. The results show that: (1) there was a positive correlation between local government land leasing revenue and house price, namely local government land leasing revenue has positive effects on house price; (2) impacts of local government land leasing revenue on house price have regional differences and time differences; (3) regional differences are mainly reflected in the differences of regional economic development level, time differences are mainly reflected in the differences of government policies at different stages. It is concluded that: local government land leasing revenue plays a very important role in the process of housing prices. In order to stabilize housing prices, it is not enough to reduce the local government land leasing revenue, and it is necessary to make comprehensive use of various control policies.
\end{abstract}

Keywords: local government land leasing revenue, house price, fixed effect model

\section{Introduction}

In recent years, with swift development of real estate industry in China, housing prices rose rapidly. As the whole country, the average sales price of house rose 128\% in 1999-2009. Analysis of survey showed that local government land leasing revenue has become one of factors that affect housing prices in the process of housing prices because of the land supply market is a non-market (XU Xiaohua \& Wu Renshui, 2010). As we all know, the government is the virtual monopoly of land ownership and the only provider in land market in China. Thus, the monopoly characteristic of land supply determines the changes in the land prices have a huge impact on house prices. In other words, the local government is a interest subject which can not ignore their own interest in the policy formulation and implementation process of the real estate market in current system of government administration (DING Jun, 2010), so how to ensure the positive interaction between land leasing revenue and house prices were received great attention. Therefore, the paper study on impacts of local government land leasing revenue on house price should be based on national and regional panel data.

Now, many scholars in world have done lots of fruitful work to the relationship of land leasing revenue and house prices. Since land price was one of the elements of housing prices, a rise in land prices will boost the long-run supply cost of houses, thereby pushing up housing prices. (BAO Zonghua, 2003) and (Bostic et al. 2007). On the contrary, research by MIAO Qihu and WANG Fanghua (2004) pointed out that the house prices driven by rising land prices, meanwhile, the variation of land supply and land supply policy had great influence on house prices.

Empirical analysis on this subject report mixed findings for different countries and regions. WANG Yuelong and ZHANG Yu (2010) pointed out that there was an interaction between land prices and house prices in China whether in the long term or in the short term. KUANG Weida (2005) also pointed out that the variation of land prices are priority to the variation of house prices in the long term and the interaction between land prices and house prices in the short term. Meanwhile, DU Hongyan, MA Yongkai, and AN Yunbi (2011) pointed out there is unidirectional Granger causality between housing and land prices in the short run: housing prices are Granger caused by land prices, while the reverse does not hold in China. Ooi and Lee (2006) pointed out that the housing and land prices are integrated in Singapore. Kim, Park, Shilling, and Cho (2008) find a bidirectional causality relationship between housing prices and land values in the U.S. market.

To sum up, most scholars in China study on relationship between land prices and house prices or Granger causality 
of the land supply based on year (quarter) macro-data, because of the test results were related to selection of lag phase and the non-stationary time series were very sensitive to research methods, so there are various conclusions. As the determinants of house prices and influence mode and size of land prices to house prices in different regions are different because of the real estate market is a regional market, so the study on year (quarter) macro-data can not reflect the heterogeneity of different regions in China, which is a major flaw in the research methods (WANG Yuelong \& WU Peng, 2009).Therefore, this paper makes the empirical analysis on the panel data of 31 different countries in period of 1999-2009 related to the land leasing revenue and house prices by using the co-integration theory, try to establish their relational model, and provide policy basis for the government to control the real estate industry.

\section{Descriptive Analysis of Local Government Land Leasing Revenue and House Price in China}

Table 1. The Descriptive Statistics of Variables

\begin{tabular}{lll}
\hline Name of Component & $\begin{array}{l}\text { Local Government Land Leasing Revenue } \\
\text { (yuan/square meter) }\end{array}$ & House Prices (yuan/square meter) \\
\hline Mean Value & 344.34 & 2963.82 \\
Median Value & 346.65 & 2778.00 \\
Maximum Value & 778.00 & 4681.00 \\
Minimum Value & 113.31 & 2053.00 \\
Standard Deviation & 219.57 & 880.78 \\
Sample Number & 341 & 341 \\
\hline
\end{tabular}

As shown in Table 1, the average land leasing revenue was 344.34 yuan in $1999-2009$, almost $11.62 \%$ of house prices, and the standard deviation of land leasing revenue and house prices is also great, so it means that there is a huge fluctuation in the land leasing revenue and house prices.

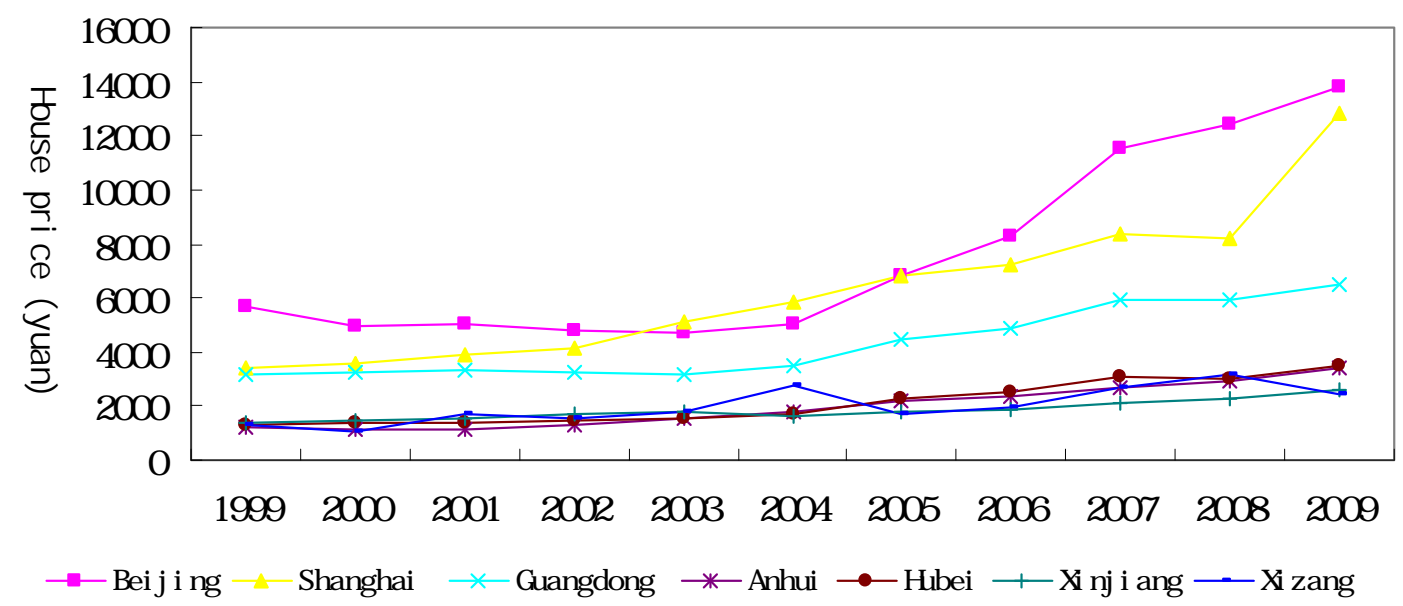

Figure 1. Typical Areas House Prices 


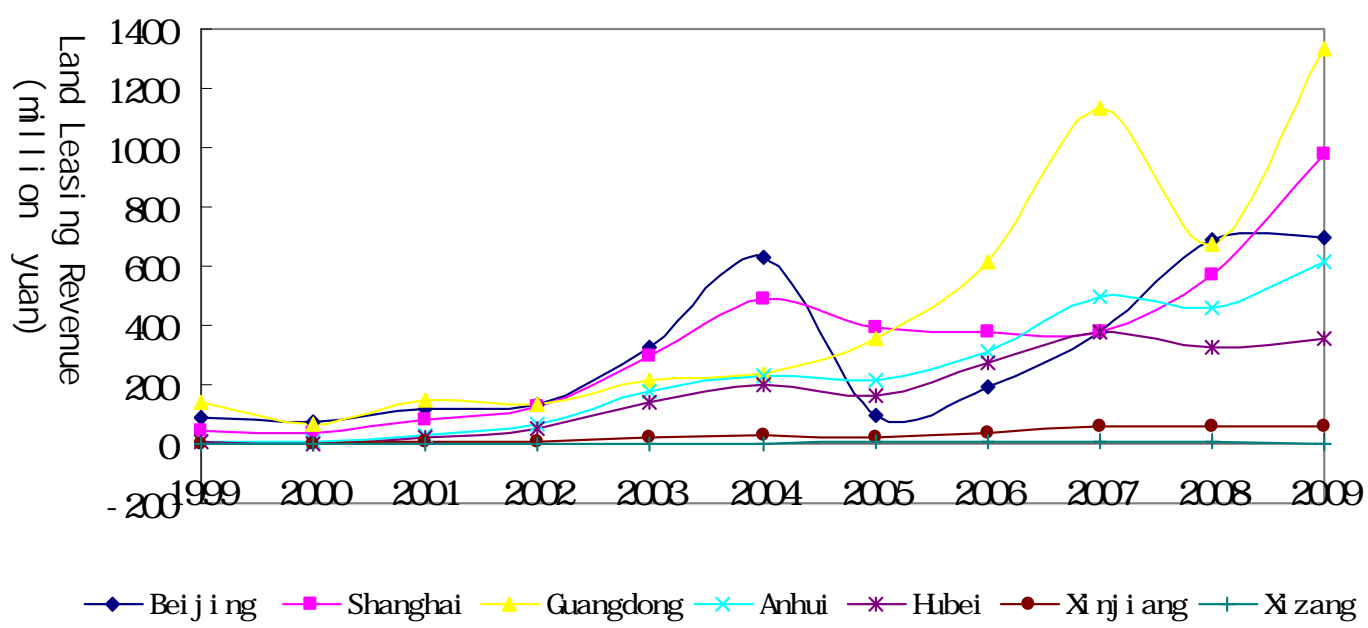

Figure 2. Typical Areas Local Government Land Leasing Revenue

As shown in Figure 1 and Figure 2, applying the approaches of graphing analysis to study the representative provinces: Beijing, Shanghai and Guangdong in the east of China, Anhui and Hubei in the center, and Xinjiang and Xizang in the west, show that the housing price and the land leasing revenue increased with the lapse of time, even though there is a slight fluctuation in the land leasing revenue. The housing price and the land leasing revenue in east areas varies greatly, prices of house and land in west areas have no obvious change and the result in middle areas fell between the prices of the former two groups. So it is necessary to make a study on house price by adopting panel data model in China where regional differences are very obvious.

\section{Research Methods, Variable Selection and Data Sources}

\subsection{Research Methods}

The co-integration theory is an extension of the traditional econometric methods which aiming at the development of cross-sectional dada, so if the sequences are not smooth, it would be prone to make spurious regression in the analysis of time series data. However, we can make these variables to the linear combination and eliminate the stochastic trend when some non-smooth vector has the same stochastic trend, which indicates that the long -term equilibrium relation between these variables. On this basis, the error correction model and the Granger causality test can be constructed to analyze the relationship between these variables.

The article makes the empirical analysis on the panel data of land leasing revenue and house prices by using the stationary and co-integration test of co-integration theory and to explain the relationship between land prices and house prices through regress analysis. At first, the paper uses unit root test for panel data to carry on stationary test and to lay a foundation for co-integration analysis. In order to overcome the deviation by using only one test method and the reality of cross-section of individual heterogeneity, so the paper uses various kinds of methods, such as LLC, Breitung, IPS, Fishier ADF and Fisher PP. Secondly, the paper explores the long-term equilibrium relation between land leasing revenue and housing prices by using Johansen co-integration test. Finally, this paper presents the correction model based on the balanced relationship between land leasing revenue and housing prices are not exist. Of course, the regressive analysis of panel data will be applied to study on impacts of regional differences and time differences based on the relationship between land leasing revenue and house prices if the long-term equilibrium relation between land leasing revenue and house prices can be defined.

\subsection{Variable Selection}

This study examines the impacts of local government land leasing revenue on house price. Therefore, taking the average sales price of house (Y) as the explained variable and representing the levels of house prices in different region and assumed that the variation of house prices can be completely attributed to the local government land leasing revenue, the local government land leasing revenue of per square meter sales of house (X) as the explanatory variable.

\subsection{Data Sources}

The study depends on the publication data from China Statistical Yearbook and China Land and Resources Statistical Yearbook 2000-2010. The researcher use the annual data series from 1999-2009 for land leasing revenue 
and house prices in 31 regions in China. The paper also makes a treatment for all panel data by using natural logarithm method.

\section{Panel Data Analysis and Establishment Model}

\subsection{Unit Root Test}

In order to ensure the reliability of conclusions, the research try to make the time series of land leasing revenue (Y) and house prices $(\mathrm{X})$ to stable by using Eviews6.0 software which includes various kinds of methods.

Table 2. Unit Roots Test of Housing Price

\begin{tabular}{|c|c|c|c|c|c|c|c|c|}
\hline \multirow{2}{*}{$\begin{array}{l}\text { Name of } \\
\text { Component }\end{array}$} & \multicolumn{2}{|c|}{ National Area } & \multicolumn{2}{|c|}{ Eastern Area } & \multicolumn{2}{|c|}{ Middle Area } & \multicolumn{2}{|c|}{ Western Area } \\
\hline & Y & $\Delta \mathrm{Y}$ & $\mathrm{Y}$ & $\Delta \mathrm{Y}$ & Y & $\Delta \mathrm{Y}$ & $\mathrm{Y}$ & $\Delta \mathrm{Y}$ \\
\hline LLC & $-7.4362 * * *$ & $-13.7515^{* * *}$ & $-2.5018 * * *$ & $-5.2169 * * *$ & $-2.7455^{* * *}$ & $-8.7120^{* * *}$ & $-6.7930 * * *$ & $-9.6149 * * *$ \\
\hline Breitung & 3.0885 & $-4.3900 * * *$ & 1.2096 & $-3.1799 * * *$ & 1.4809 & $-3.2206 * * *$ & 2.4625 & $-1.3789 *$ \\
\hline IPS & -0.4705 & $-3.2273 * * *$ & 0.4291 & -1.0465 & 0.5829 & $-2.7291 * * *$ & $-1.4540^{*}$ & $-1.9005 * *$ \\
\hline Fisher ADF & 69.5182 & $137.1660 * * *$ & 18.7563 & $36.6289^{* *}$ & 15.5531 & $53.0995 * * *$ & $35.2088^{* *}$ & $47.4373 * * *$ \\
\hline Fisher PP & $81.2528^{*}$ & $187.1430 * * *$ & 23.2378 & $36.8375^{* *}$ & 15.1548 & $96.5801 * * *$ & $42.8602 * * *$ & $53.7251 * * *$ \\
\hline
\end{tabular}

Note: $\Delta$ Variable time difference, inspection original hypothesis are put in unit root. Lag selection using Schwarz standard automatic selection, inspection form include constant and trend, ${ }^{*}, *$ and $* *$ denote significance at the $10 \%, 5 \%$ and $1 \%$ levels, respectively.

Table 3. Unit Roots Test of Land Leasing Revenue

\begin{tabular}{l|l|l|l|l|l|l|l|l}
\hline \multirow{2}{*}{$\begin{array}{l}\text { Name } \\
\text { Component }\end{array}$} & \multicolumn{2}{|c|}{ National Area } & \multicolumn{2}{c|}{ Eastern Area } & \multicolumn{2}{c}{ Middle Area } & \multicolumn{2}{c}{ Western Area } \\
\cline { 2 - 10 } & \multicolumn{1}{|c|}{$\mathrm{Y}$} & \multicolumn{1}{|c|}{$\Delta$} & $\mathrm{Y}$ & $\Delta \mathrm{Y}$ & $\mathrm{Y}$ & $\Delta \mathrm{Y}$ & $\mathrm{Y}$ & $\Delta \mathrm{Y}$ \\
\hline LLC & $-10.8989^{* * *}$ & $-16.6281^{* * *}$ & $-6.8158^{* * *}$ & $-10.9899^{* * *}$ & -8.8926 & $-9.2290^{* * *}$ & -1.0906 & $-8.4926^{* * *}$ \\
\hline Breitung & -1.0003 & $-2.9368^{* * *}$ & -1.0312 & $-3.6583 * * *$ & -0.1697 & $-4.3074 * * *$ & -0.6417 & -0.5054 \\
\hline IPS & -8.5511 & $-3.6504 * * *$ & $-1.6370^{*}$ & $-2.4398^{* * *}$ & -0.8463 & $-2.3677^{* * *}$ & 0.8232 & $-1.4975^{*}$ \\
\hline Fisher ADF & 73.3925 & $151.0650^{* * *}$ & $37.3072^{* *}$ & $60.1463^{* * *}$ & 25.4088 & $49.5089^{* * *}$ & 10.6764 & $41.4102^{* * *}$ \\
\hline Fisher PP & $76.6472^{*}$ & $291.1830^{* * *}$ & $60.4595^{* * *}$ & $90.2081^{* * *}$ & 6.0678 & $64.8093^{* * *}$ & 0.1200 & $64.1658^{* * *}$ \\
\hline
\end{tabular}

Note: $\Delta$ Variable time difference, inspection original hypothesis are put in unit root. Lag selection using Schwarz standard automatic selection, inspection form include constant and trend, ${ }^{*}, *$ and $* * *$ denote significance at the $10 \%, 5 \%$ and $1 \%$ levels, respectively.

As shown in Table 2 and Table 3, the result of empirical analysis showed that all samples or the samples of various regions could not reject the existence of unit root null hypothesis while the regression equation included constant and trend, so the sequence of land leasing revenue and house prices were not smooth. But the series of house prices $(\mathrm{Y})$ and land leasing revenue $(\mathrm{X})$ showed their first-order difference stationary, I (1) process, by the unit root test.

\subsection{Co-integration Test}

The series of house prices $(\mathrm{Y})$ and land leasing revenue (X) showed their first-order difference stationary, I (1) process, by the unit root test. On the basis of the result unit root test, we had practiced Johansen Fisher co-integration test and analyzed the long-term equilibrium relation between the series of house prices and land leasing revenue. 
Table 4. Results of Johansen Fisher Co-integration Test on Panel Data

\begin{tabular}{l|c|c|c|c|c|c|c|c}
\hline $\begin{array}{l}\text { Name of } \\
\text { Component }\end{array}$ & \multicolumn{2}{|c|}{ National Area } & \multicolumn{2}{c|}{ Eastern Area } & \multicolumn{2}{c}{ Middle Area } & \multicolumn{2}{c}{ Western Area } \\
\hline $\begin{array}{l}\text { Hypothesized } \\
\text { No. of CE(s) }\end{array}$ & Trace Test & $\begin{array}{c}\text { Max-Eign } \\
\text { Test }\end{array}$ & Trace Test & $\begin{array}{c}\text { Max-Eign } \\
\text { Test }\end{array}$ & Trace Test & $\begin{array}{c}\text { Max-Eign } \\
\text { Test }\end{array}$ & Trace Test & $\begin{array}{c}\text { Max-Eign } \\
\text { Test }\end{array}$ \\
\cline { 2 - 9 } None & $272.20^{* * *}$ & $250.10^{* * *}$ & $99.68^{* * *}$ & $95.37 * * *$ & $117.20^{* * *}$ & $104.40^{* * *}$ & $55.35^{* * *}$ & $50.32^{* * *}$ \\
At most 1 & 115.60 & 115.60 & 36.08 & 36.08 & 45.42 & 45.42 & 34.07 & 34.07 \\
\hline
\end{tabular}

Note: Inspection form choice sequences are deterministic trend, and co-integration equation with constants and trend, the brackets to estimate the amount of concomitant probability, $* * *$ and $* * *$ denote significance at the $10 \%, 5 \%$ and $1 \%$ levels, respectively.

As shown in Table 4, all samples or the samples of various regions refused the existence of co-integration at the $1 \%$ significant level. That means the long-term equilibrium relation between the series of house prices $(\mathrm{Y})$ and land leasing revenue $(\mathrm{X})$ can be defined.

\subsection{Establishment Model}

The result of co-integration test showed that the long-term equilibrium relation between the series of house prices (Y) and land leasing revenue $(\mathrm{X})$ can be defined, so we can use regressing analysis directly because the phenomenon of spurious regression does not exist. There are three empirical models can be chosen according to the differences in different regions and times, such as the mixed effect model, fixed effect model and random effect model. F test and Huasman test showed that we should study on impacts on local government land leasing revenue and house prices in different regions and times by using the fixed effect model. So either all samples or the samples of various regions of panel data are made the fixed effect variable intercept model which includes constant individual and time. The fixed effect model is as follows:

$$
Y_{i t}=m+\beta X_{i t}+\alpha_{i}^{*}+\gamma_{t}+v_{i t} \quad(i=1,2, \ldots, N ; \quad t=1,2, \ldots, T)
$$

In the formula, $Y_{i t}$ is as house prices in different regions and times, $X_{i t}$ is as the land leasing revenue in different regions and times, $\alpha_{i}^{*}$ is as variables of regional differences, which reflect individual differences impact on house prices, $\gamma_{t}$ is as variables of time differences, which reflect time differences impact on house prices, $v_{i t}$ is as stochastic error, $I$ is as the number of individual, $t$ is as the time advance.

\section{Analysis of Results}

\subsection{Analysis of Results in the Whole Country}

The house price is the explained variable and the local government land leasing revenue of per square meter sales of house is the explaining variable in the regression model.

Table 5. Estimated Impacts of Local Government Land Leasing Revenue on House Price

\begin{tabular}{lllll}
\hline Name of Component & National & Eastern & Middle & Western Area \\
& Area & Area & Area & \\
\hline Influence Coefficient of C & $7.4685^{* * *}$ & $7.5016^{* * *}$ & $7.3383^{* * *}$ & $7.4328^{* * *}$ \\
Influence Coefficient of Local Government Land Leasing Revenue & $0.0370^{* * *}$ & $0.0794^{* * *}$ & 0.0193 & 0.0135 \\
Adjusted $\mathrm{R}^{2}$ & 95.12 & 96.22 & 93.57 & 84.40 \\
F Statistics & $162.6349^{* * *}$ & $152.9837^{* * *}$ & $76.0521^{* * *}$ & $30.4837^{* * *}$ \\
\hline
\end{tabular}

Note: $* * *$ and $* * *$ denote significance at the $10 \%, 5 \%$ and $1 \%$ levels, respectively.

As shown in Table 5, the results of analysis shows that the local government land leasing revenue has positive effects on house prices and the coefficients of effect of land leasing revenue on house prices is 0.037 , namely the land leasing revenue increases one percentage point, the house prices will rise by 0.037 percentage points. 
Table 6. Coefficients of Individual and Time Fixed Influences

\begin{tabular}{|c|c|c|c|c|c|c|c|}
\hline \multicolumn{6}{|c|}{$\alpha \mathrm{i}(\mathrm{i}=1,2, \ldots, 31)$} & \multicolumn{2}{|c|}{$\mathrm{Wt}(\mathrm{t}=1,2, \ldots, 11)$} \\
\hline \multicolumn{2}{|c|}{ Eastern Area } & \multicolumn{2}{|c|}{ Middle Area } & \multicolumn{2}{|c|}{ Western Area } & \multicolumn{2}{|c|}{ National Area } \\
\hline Liaoling & 0.1630 & Shanxi & -0.2537 & Shanxi & -0.1621 & 1999 & -0.3283 \\
\hline Beijing & 1.1093 & Neimenggu & -0.2988 & Gansu & -0.2902 & 2000 & -0.3042 \\
\hline Tianjin & 0.4446 & Jilin & -0.1668 & Qinghai & -0.2357 & 2001 & -0.2607 \\
\hline Hebei & -0.2029 & Heilongjiang & -0.0356 & Ningxia & -0.1137 & 2002 & -0.2327 \\
\hline Shandong & -0.0881 & Anhui & -0.2011 & Xinjiang & -0.1883 & 2003 & -0.2018 \\
\hline Jiangsu & 0.1545 & Jiangxi & -0.4666 & Chongqing & -0.1277 & 2004 & -0.0922 \\
\hline Shanghai & 0.9454 & Henan & -0.2944 & Sichuan & -0.1709 & 2005 & 0.0728 \\
\hline Zhejiang & 0.4024 & Hubei & -0.1200 & Guizhou & -0.3132 & 2006 & 0.1549 \\
\hline Fujian & 0.2670 & Hunan & -0.3383 & Yunnan & -0.0426 & 2007 & 0.3087 \\
\hline Guangdong & 0.6090 & & & Xizang & -0.1390 & 2008 & 0.3686 \\
\hline Guangxi & -0.0761 & & & & & 2009 & 0.5150 \\
\hline Hainan & 0.2306 & & & & & & \\
\hline
\end{tabular}

As shown in Table 6, the paper also considered the factor of period and the time fixed effects coefficient in order to make further analysis of the impact of land leasing revenue on house prices. There is a tendency for time effects coefficient to show a gradual increase in 1999-2009. All these indicated that the land leasing revenue plays an increasing important role in house price and it also increasingly becoming the main source of local government revenue. At the same time, that is also consistent with the realism of local government revenue sources in our country.

\subsection{Analysis of Results in Different Regions}

According to the division of geographical area, the paper analyzes the impact of local government land leasing revenue on house price in each area respectively. On one hand, the impact of local government land leasing revenue on house price has significant regional differences, while the effects shows a gradual decrease from east to west. This is because the east area is the most economic developed districts in our country with rapid industrialization and urbanization which have attracted many people to come to settle, so all these lead to increased demand for housing. However, housing construction is always built on the basis of land and the land resources in east area are much less than those in other areas, so it raises the land prices once more.

On the other hand, the individual fixed effects coefficient is positive number in east area except individual provinces, while the individual fixed effects coefficient is negative number in middle area and west area. The results of analysis indicated that the impact of land leasing revenue on house prices in east area is much stronger than that in other areas at the same period. However, the impact of land leasing revenue on house prices in middle area and west area is not obvious, this is because there are many people in middle area, and the land resources are much less than those in west area, so there is little land for selling. Meanwhile, the function of economic fundamental of Sichuan and Chongqing in west area also plays an important role in promoting housing prices. Therefore, the differences of impact of land leasing revenue on house prices in middle area and west area are not very obvious, as table 5 shows.

\section{Conclusion and Suggestion}

\subsection{Conclusion}

The article makes the empirical analysis on the panel data of land leasing revenue and house prices by using the stationary and co-integration theory and explains the relationship between land prices and housing prices through regress analysis. The results show that: (1) there is a positive correlation between local government land leasing revenue and house price, namely local government land leasing revenue has positive effects on house price; (2) impacts of local government land leasing revenue on house price have regional differences and the differences are mainly reflected in the differences of regional economic development level, namely the impacts of local government land leasing revenue on house price in east area are larger than those in middle area and west area; (3) impacts of local government land leasing revenue on house price have time differences and the differences are mainly reflected in the differences of government policies at different stages. 


\subsection{Suggestion}

The results of study on impacts of local government land leasing revenue on house price have important reference meaning to reform the local government revenue in China and develop the real estate market in different regions. It is concluded that:

(1) The rising house prices are caused by over-reliance on land financial of local government, so In order to stabilize housing prices, we should standardize the behavior of land sale or establish the Land Fund to change the behavior of local government which overdraft land and blind planning ,but not only reduce the local government land leasing revenue We also can make comprehensive use of various control policies to stable house prices, such as improving the real estate taxation system and increasing tax category in the house holding link, so we can reach the goals which fight against behavior of house and increase the sources of local financial.

(2) The results of analysis show the unbalanced development in real estate market in different regions in China. On one hand, we should encourage local government to make developing financial revenue policy and to make fiscal expenditure plans conform to reality. On the other hand, in order to make the coordinated development of real estate in different regions come true, the central government should increase investment in local public services through financial transfer payment in middle area and west area.

\section{References}

Hongyan Du, Yongkai Ma, \& Yunbi An. (2011). The impact of land policy on the relation between housing and land prices: Evidence from China. The Quarterly Review of Economics and Finance, 1, 19-27. http://dx.doi.org/10.1016/j.qref.2010.09.004

Joseph T. L., Ooi, C., F. Sirmans, \& Geoffrey K. Turnbull. (2006). Price Formation Under Small Numbers Competition: Evidence from Land Auctions in Singapore. Real Estate Economics, 1, 51-76. http://dx.doi.org/10.1111/j.1540-6229.2006.00159.x

Jun Ding. (2010). Impacts of Land Revenue on Real Estate Market Price. China Urban Economy, 10, 32-33.

Kim, K. H., Park, Y. J., Shilling, J. D., \& Cho, H. (2008). Do Higher Land Values Cause Higher House Prices, or Vice Versa? Working paper, KAIST Business School, available from SSRN: http://papers.ssrn.com/sol3/papers.cfm?abstract_id=1300821

Qi-hu MIAO, \& Fang-hua WANG. (2004). What are Cause and Effects of the Rise of House Price and Land Price? Price: theory \& Practice, 12, 46-47.

Raphael W. Bostic, Stanley D. Longhofer, \& Christian L. Redfearn. (2007). Land Leverage: Decomposing Home Price Dynamics. Real Estate Economics, 2, 183-208. http://dx.doi.org/10.1111/j.1540-6229.2007.00187.x

Stefan De Wachter, Richard D. F. Harris, \& Elias Tzavalis. (2007). Panel data unit roots tests: The role of serial correlation and the time dimension. Journal of Statistical Planning and Inference, 1, 230-244. http://dx.doi.org/10.1016/j.jspi.2005.11.004

Tiemei Gao. (2006). Econometric Methods and Modeling: Application and Example of Eviews. Beijing: Tsinghua University Press.

We-da Kuang. (2005). A Study on the Relationship Between Housing Pricing and Land Pricing: Basic Model and Evidence from China. Finance \& Trade Economics, 11, 56-63.

Xiao-hua Xu, \& Ren-shui Wu. (2010). Research on the Dynamic Adjustment Relationship Between Housing Price and Land Price. China Land Science, 4, 38-50.

Yue-long Wang, \& Peng Wu. (2009). Re-inspection on the Relationship Between Housing Price and Land Price From the Panel Data of China's 28 Provinces. Nankai Economic Studies, 4, 132-142.

Yue-long Wang, \& Yu Zhang. (2010). Study on the Relationship between the Housing Price and Land Price Based on Chinese Provincial Panel Data. Journal of Shanxi Finance and Economics University, 1, 50-57.

Yun-peng SHI. (2011). Research on Relationship Between Economics and Real Estate Market in China Based on Co-integration Theory. Economic Outlook the Bohai Sea, 8, 33-34.

Zinai Li, \& Wenqing Pan. (2005). Econometrics. Beijing: Higher Education Press.

Zong-hua Bao. (2003). Analysis on Bubble Economy and Real Estate Industry. China Real Estate, 9, 30-33. 